\title{
Pathogen-specific effects on milk yield in repeated clinical mastitis episodes in Holstein dairy cows
}

\author{
J. A. Hertl, ${ }^{\star 1}$ Y. H. Schukken, ${ }^{\star}$ F. L. Welcome, $†$ L. W. Tauer,‡ and Y. T. Gröhn* \\ ${ }^{*}$ Section of Epidemiology, Department of Population Medicine and Diagnostic Sciences, College of Veterinary Medicine, \\ †Quality Milk Production Services, Department of Population Medicine and Diagnostic Sciences, College of Veterinary Medicine, and \\ $\ddagger$ Charles H. Dyson School of Applied Economics and Management, College of Agriculture and Life Sciences, Cornell University, Ithaca, NY 14853
}

\section{ABSTRACT}

The objective of this study was to estimate the effects of clinical mastitis (CM) cases due to different pathogens on milk yield in Holstein cows. The first $3 \mathrm{CM}$ cases in a cow's lactation were modeled. Eight categories of pathogens were included: Streptococcus spp.; Staphylococcus aureus; coagulase-negative staphylococci (CNS); Escherichia coli; Klebsiella spp.; cases with CM signs but no bacterial growth (above the level detectable by our microbiological procedures) observed in the culture sample, and cases with contamination ( $\geq 3$ pathogens in the sample); other pathogens that may be treated with antibiotics (included Citrobacter, Corynebacterium bovis, Enterobacter, Enterococcus, Pasteurella, Pseudomonas; "other treatable"); and other pathogens not successfully treated with antibiotics (Trueperella pyogenes, Mycoplasma, Prototheca, yeasts; "other not treatable"). Data from 38,276 lactations in cows from 5 New York State dairy herds, collected from 2003-2004 until 2011, were analyzed. Mixed models with an autoregressive correlation structure (to account for correlation among the repeated measures of milk yield within a lactation) were estimated. Primiparous (lactation 1) and multiparous (lactations 2 and 3) cows were analyzed separately, as the shapes of their lactation curves differed. Primiparas were followed for up to $48 \mathrm{wk}$ of lactation and multiparas for up to $44 \mathrm{wk}$. Fixed effects included parity, calving season, week of lactation, CM (type, case number, and timing of CM in relation to milk production cycle), and other diseases (milk fever, retained placenta, metritis, ketosis, displaced abomasum). Herd was modeled as a random effect. Clinical mastitis was more common in multiparas than in primiparas. In primiparas, Streptococcus spp. occurred most frequently as the first case. In multiparas, E. coli was most common as the first case. In subsequent cases, CM cases with no specific growth

Received July 18, 2013.

Accepted November 15, 2013.

${ }^{1}$ Corresponding author: jah12@cornell.edu or contamination were most common in both parity groups. The hazard of CM increased with case number. Mastitic cows were generally higher producers before the CM episode than their nonmastitic herdmates. Milk loss varied with pathogen and case number. In primiparas, the greatest losses were associated with $E$. coli and "other not treatable" organisms. In multiparas, the greatest losses were associated with Klebsiella spp. and "other not treatable" organisms. Milk loss was not associated with occurrence of CNS. The findings may help farmers to make optimal management decisions for their cows.

Key words: milk yield, mastitis, pathogen, mixed model

\section{INTRODUCTION}

Clinical mastitis (CM) is an ongoing problem in many dairy herds around the world. In addition to reduced cow welfare and increased veterinary costs, episodes of $\mathrm{CM}$ are associated with markedly reduced milk production (Houben et al., 1993; Bar et al., 2007; Hagnestam et al., 2007; Schukken et al., 2009b), decreased fertility (Santos et al., 2004; Hertl et al., 2010), and increased risk of culling and death (Waage et al., 2000; Hertl et al., 2011).

Clinical mastitis may be due to a wide variety of organisms and may occur multiple times within a single lactation and across lactations. Because large differences exist between major mastitis pathogens in the pathobiology of inflammatory response after an IMI (Schukken et al., 2011), it may be expected that milk production losses will be different between pathogens. Precise knowledge of pathogen-specific milk loss is important for decision making in regard to treatment and production prognosis of affected cows, including replacement decisions.

Pathogen-specific milk losses are not just of recent concern. In a British study, mastitic cows from which no organisms were isolated had slightly higher milk yields than nonmastitic cows, whereas cows with Streptococcus agalactiae, Streptococcus dysgalactiae, Streptococcus uberis, or staphylococci infections had 
significantly lower yields (King, 1969). Natzke et al. (1972) found that coliforms, streptococci, and Staphylococcus aureus, among other organisms, were associated with $305-\mathrm{d}$ milk losses of $>500 \mathrm{~kg}$. In a Michigan study, cows with CM lost over $300 \mathrm{~kg}$ of milk during the $60 \mathrm{~d}$ after diagnosis (including both actual losses and milk withheld due to antibiotic treatment); in that study, milk loss did not vary substantially with etiologic agent (Streptococcus spp., Staph. aureus, CNS, coliforms, others). The authors reported that milk loss was higher for first cases $(366 \mathrm{~kg})$ than for subsequent cases $(300 \mathrm{~kg})$, although this difference was not statistically significant (Bartlett and van Wijk, 1991). In our previous studies on repeated cases, we determined that a second case with an organism of the same Gram classification as the first case in the same lactation did not differ in milk loss compared with a second case with an organism of a different Gram classification (Schukken et al., 2009b).

The incidence rate of the next case of CM of the same pathogen as the previous case was shown to increase after a previous case of CM. Among cows that had experienced a first case of CM in lactation, we observed a higher incidence rate of second cases, and among cows with 2 cases of $\mathrm{CM}$, the rate of third cases was again higher (Bar et al., 2008). Similar to the incidence rate and persistent high loss of repeated cases of mastitis within a single lactation, the risk of death was similar in multiparous cows after every occurrence of $\mathrm{CM}$ in the same lactation and the risk of culling increased with every occurrence of mastitis in both primiparous and multiparous cows (Bar et al., 2008).

All these findings, somewhat surprisingly, indicate no immunological benefit of a previous case of $\mathrm{CM}$ with regard to the ability to respond to the next case of $\mathrm{CM}$, even when the 2 subsequent cases involved organisms of the same Gram classification. Of course, the similarity of Gram classification does not guarantee that the first and second cases were caused by the same pathogen. A more detailed analysis that includes knowledge of the actual pathogen is therefore needed to better understand the biology and possible presence or absence of reduced severity of multiple cases of CM with the same pathogen.

For these reasons, considerable biological-immunological and management interest exists in pathogenspecific milk loss data in case of a first or recurrent episode of CM. This study explores that issue as part of a progression of the work our group has done on CM for several years. We first studied the effects of the first case of pathogen-specific CM in a single lactation on milk yield (Gröhn et al., 2004). We later examined the effect of recurrent cases of pathogen-unidentified CM on milk yield (Bar et al., 2007). We have collected sufficient data to study the effects of different groupings (gram-positive, gram-negative, other) of recurrent CM cases on milk yield (Schukken et al., 2009b). We have now accumulated sufficient additional data to study recurrent cases of pathogen-specific CM. The objective of this study was to estimate the effects of episodes of CM caused by specific pathogens on milk yield (mean daily yield in each week) throughout lactations in Holstein dairy cows.

\section{MATERIALS AND METHODS}

\section{Herd Descriptions}

Five well-managed, high-producing Holstein herds, 3 from central New York State, 1 from northern New York, and 1 from western New York, with an average herd size of 1,140 cows, participated in the study. The 305-d rolling herd average milk production ranged from 11,260 to $13,123 \mathrm{~kg} /$ cow per year; monthly mean SCC ranged from 137,000 to 262,000 cells $/ \mathrm{mL}$. Data on milk production, milk conductivity, parity, reproduction success, diseases, calving, drying-off, and herd exit were available for 7 to 8 yr. Farm personnel used DairyComp305 herd management software (Valley Agricultural Software, Tulare, CA) to record information. Cows were housed in freestalls in covered barns and were managed in groups according to lactation month, production, and reproduction status. They were fed a balanced TMR and milked 3 times daily.

\section{Case Definition}

All lactating cows in the 5 herds were eligible for inclusion in the study. Milkers discovered most CM cases, characterized by a warm, swollen udder or changes in milk consistency. Additional cases were found by herdspersons examining cows whose milk electrical conductivity was elevated ( $>115 \%$ of the average of the previous $10 \mathrm{~d}$ ) and that experienced a sudden concurrent milk loss $(<70 \%$ of the average of the previous 10 d). Sick cows were treated according to well-defined protocols that were similar across the 5 farms and throughout the study. Farm personnel collected milk samples from quarters with signs of CM and sent them to the Quality Milk Production Services laboratories (in Ithaca, Canton, and Geneseo, NY) for culturing (Hertl et al., 2011). The bacteriological culture procedures used in this study are described in detail in Gröhn et al. (2004).

If 2 different pathogens (e.g., Streptococcus spp. and Staph. aureus) were isolated from the same or a different quarter on the same day, both contributed to the analysis. That is, both Streptococcus spp. and Staph. aureus were considered causative agents of that 
particular CM case. When 3 or more pathogens were recorded on the same day, the sample was considered contaminated.

If a second $\mathrm{CM}$ episode occurred in the same quarter within $5 \mathrm{~d}$ after the first episode (with the same or a different etiologic agent isolated) or occurred within $14 \mathrm{~d}$ with the same etiologic agent isolated from both episodes, it was considered to be the same case of CM. In the former situation (second episode occurring in the same quarter $\leq 5 \mathrm{~d}$ after the first), the cause of $\mathrm{CM}$ was coded as the first-occurring pathogen. Any episode occurring $>14 \mathrm{~d}$ after the previous episode, regardless of the pathogen isolated, was considered a new CM case (Barkema et al., 1998; Hertl et al., 2011). Although CM episodes were characterized at the quarter level, the unit of analysis in this study was a cow in a given lactation.

Eight categories of pathogens were modeled: Streptococcus spp. [includes Strep. dysgalactiae, Strep. uberis, other gram-positive catalase-negative cocci (such as Streptococcus aerococcus, Streptococcus enterococcus, Streptococcus lactococcus), and other Streptococcus spp.]; Staph. aureus; staphylococci other than Staph. aureus (referred to as CNS throughout); Escherichia coli; Klebsiella spp.; cases with CM signs but no bacterial growth (above the level that could be detected from our microbiological procedures) observed in the culture sample and cases with contamination $(\geq 3$ pathogens in the sample); other pathogens that may be treated with antibiotics (includes Citrobacter, Corynebacterium bovis, Enterobacter, Enterococcus, Pasteurella, Pseudomonas; "other treatable"); and other pathogens that are not successfully treated with antibiotics (Trueperella pyogenes, Mycoplasma, Prototheca, yeasts; "other not treatable").

\section{Other Diseases}

The focus of this study was milk loss patterns in recurrent episodes of CM caused by the same or different pathogens. Five other diseases [milk fever, retained placenta, metritis, ketosis, and displaced abomasum (DA)] were included in the models to account for their potential effects on milk production. They were defined as follows (Gröhn et al., 2004): (1) milk fever: a cow was unable to rise or had cool extremities and sluggish rumen motility near the time of calving, but was successfully treated with calcium; (2) retained placenta: retention of fetal membranes for at least $24 \mathrm{~h}$ after calving; (3) metritis: a cow was febrile and had a purulent or fetid vaginal discharge, or an enlarged uterus detected by veterinary palpation; (4) ketosis: presence of ketones in milk or urine; and (5) DA: an abomasum enlarged with fluid, gas, or both, that was mechanically trapped in either the left or right side of the abdominal cavity. Written disease definitions were provided to participating dairy producers and veterinarians to ensure consistency in disease definition and diagnostic criteria across study farms.

\section{Statistical Analysis}

The effects of recurrent episodes of pathogen-specific $\mathrm{CM}$ and other factors, including parity, calving season, week-in-milk (WIM; i.e., week of lactation), and other diseases, on milk yield (mean daily milk production, $\mathrm{kg} / \mathrm{d}$, in a particular WIM) were estimated using mixed models (PROC MIXED in SAS version 9.2, 2009; SAS Institute Inc., Cary, NC, ). A first-order autoregressive correlation structure among the repeated measurements of milk yield within a cow's lactation was incorporated; such a structure assumes that measurements occurring closer in time are more highly correlated than measurements occurring further apart in time. These models were adapted from earlier research on the effects of recurrent pathogen-unidentified CM cases (Bar et al., 2007) and recurrent type-specific (gram-positive, gramnegative, other) CM cases (Schukken et al., 2009b) on milk yield. Primiparous cows (cows in their first lactation, primiparas) and multiparous cows (cows in their second or third lactations, multiparas) were modeled separately, as the shapes of their lactation curves differed markedly. Cows above parity 3 were excluded from all analyses, as adequate precision of parameter estimates could not be obtained when they were included in the multiparous model (the standard errors of the estimates were unacceptably large). The first $3 \mathrm{CM}$ episodes occurring in a given lactation were included in the analysis; too few fourth (69 and 294 cases across all pathogens in primiparas and multiparas, respectively) and higher-order cases were present for inclusion. Time to event curves (survival curves) were created for the time to the first, second, and third cases of CM using Kaplan-Meier estimates (Schukken et al., 2010).

All covariates except herd were modeled as fixed effects. Herd was modeled as a random effect because the interest of this study was not in any particular farm, but rather in farms in general with the same characteristics as those in the study (large, high-producing, and having a low incidence of contagious mastitis). The following linear mixed model was used:

$$
\begin{aligned}
& \text { Y }=\text { Strep._spp._index }+ \text { Staph._aureus_index } \\
& + \text { CNS_index + E._coli_index + Klebsiella_spp._- } \\
& \text { index + No_growth_index + Other_treated_index } \\
& + \text { Other_not_treated_index + Parity + Calving } \\
& \text { season + WIM + Other diseases + Herd + Re, [1] }
\end{aligned}
$$


where Y is daily milk production $(\mathrm{kg} / \mathrm{d})$; Strep._spp._ index ... Other_not_treated_index represent index variables for time before or after a specific type of CM occurred in relation to when the milk measurements were recorded (see below and Table 1 for details); parity had levels 2 and 3 (used only in the model for multiparas); calving season had 4 categories [winter (January, February, March), spring (April, May, June), summer (July, August, September), autumn (October, November, December)]; WIM had 48 levels in the primiparous model and 44 levels in the multiparous model (choice of follow-up time was based on model convergence and precision of parameter estimates); "other diseases" represents index variables for time before or after a certain disease (milk fever, retained placenta, metritis, ketosis, DA) occurred in relation to when the milk measurements were recorded; herd (random effect) had 5 levels (one for each farm), and Re is a complex error term containing an autoregressive term and a random residual. The autoregressive term accounts for clustering of observations within lactation. Clustering of lactations within cow could not be handled statistically. Statistical significance was defined at $P<0.05$.

As mentioned above, separate indices (Strep.spp._index ... Other_not_treated_index) for each type of CM (due to a different pathogen) were created, representing when milk weights were measured in relation to occurrence of a specific type of CM: $0=$ free of that type of CM; I_J where I is first, second, or third occurrence of $\mathrm{CM}$, denoted as 1,2 , or 3 , and $\mathrm{J}$ is the week before or after that occurrence of $\mathrm{CM}$, denoted as $-3(\geq 3 \mathrm{wk}$ before the case), -2 ( 2 wk before the case), -1 ( $1 \mathrm{wk}$ before the case), 1 (1 wk after the case), 2 (2 wk after the case), $3, \ldots, 8$ ( $8 \mathrm{wk}$ after the case), and 9 ( $\geq 9 \mathrm{wk}$ after the case). Thus, each index had 31 levels (1 representing no $\mathrm{CM}$ of that type in the lactation (the reference group), 12 levels for timing of milk measurements in relation to the first $\mathrm{CM}$ case, 9 levels for timing of milk measurements in relation to the second $\mathrm{CM}$ case, and 9 levels for timing of milk measurements in relation to the third CM case). This coding scheme is illustrated in Table 1 for 4 example cows: one without CM during lactation; one with $E$. coli $\mathrm{CM}$ in wk 9; one with $E$. coli in wk 5 and Streptococcus spp. twice (in wk 5 and 9); and one with $3 \mathrm{CM}$ cases (E. coli in wk 3 ; Staph. aureus in wk 12; and Streptococcus spp. in wk 16).

An important point to remember in interpretation is that, for example, if a cow has Streptococcus spp. in her first CM case, her second (or third) case could be due to any pathogen, not necessarily Streptococcus spp. again; we applied similar reasoning to second and third cases.

Similar indices were created when milk weights were measured in relation to occurrence of the non-CM diseases. For milk fever and retained placenta, the indices had 10 levels: $0=$ no disease during lactation; $1=$ week of occurrence of disease; $2=$ second week after occurrence of disease; $3=$ third week after occurrence; ...; $8=$ eighth week after occurrence; $9=9$ or more weeks after occurrence of disease. Both of these diseases (milk fever and retained placenta) occurred only in the first week of lactation.

For metritis, ketosis, and DA, the indices had 11 levels: $0=$ no disease; $-1=$ before disease occurred; 1 = week of occurrence of disease; $2=$ second week after occurrence of disease; $3=$ third week after occurrence; $\ldots ; 8=$ eighth week after occurrence; $9=9$ or more weeks after occurrence of disease.

Additional analysis was conducted on milk yield, for primiparas and multiparas separately, to determine if a difference existed between repeated cases with the same versus different pathogens. Here, only cows that experienced a second or third case of $\mathrm{CM}$ and cows that did not experience CM, were included. Two categorical variables were created, one for comparison of cases 1 and 2 (Previous_Pathogen12), and the other for comparison for cases 2 and 3 (Previous_Pathogen23). For comparing cases 1 and 2, Previous_Pathogen $12=$ "same" if the causative pathogens in cases 1 and 2 were the same, and Previous_Pathogen $12=$ "different" if the causative pathogens in cases 1 and 2 were different. For comparing cases 2 and 3, Previous_Pathogen23= "same" if the causative pathogens in cases 2 and 3 were the same, and Previous_Pathogen23 = "different" if the causative pathogens in cases 2 and 3 were different. The reference level for both Previous_Pathogen12 and Previous_Pathogen23 was "none"; that is, if the cow did not have CM at all.

\section{RESULTS}

\section{Descriptive Findings}

Results were based on 17,265 primiparous lactations followed for up to $48 \mathrm{wk}$ of lactation and 21,011 multiparous lactations [parities $2(\mathrm{n}=12,984)$ and 3 (n $=8,027$ )] in 14,405 cows followed for up to $44 \mathrm{wk}$ of lactation. Table 2 shows the distribution of pathogens and cases in primiparas and multiparas. Clinical mastitis occurred more frequently in multiparas than in primiparas. In primiparas, Streptococcus spp. occurred most frequently as the first case. In subsequent cases, no specific growth or contamination was most common. In multiparas, E. coli was most common as the first case. In a second or third case, no growth or contamination was most common.

\section{Risk of First and Repeated Cases}

Figure 1 shows the time to event (case of CM) curves (survivor function) for the first $3 \mathrm{CM}$ cases (of 
Table 1. Covariate coding scheme used in the statistical analysis of this study for 4 example cows (1, 2, 3, and 4) and 3 pathogens (Streptococcus spp., Escherichia coli, and Staphylococcus aureus); the other pathogens are coded similarly but are not shown here ${ }^{1,2}$

\begin{tabular}{|c|c|c|c|c|c|c|c|c|c|c|c|c|}
\hline \multirow[b]{2}{*}{$\begin{array}{l}\text { Week } \\
\text { in milk }\end{array}$} & \multicolumn{3}{|c|}{ Cow 1} & \multicolumn{3}{|c|}{ Cow 2} & \multicolumn{3}{|c|}{ Cow 3} & \multicolumn{3}{|c|}{ Cow 4} \\
\hline & $\begin{array}{l}\text { I_J for } \\
\text { Strep. spp. }\end{array}$ & $\begin{array}{l}\text { I_J for } \\
\text { E. coli }\end{array}$ & $\begin{array}{c}\text { I_J for } \\
\text { Staph. aureus }\end{array}$ & $\begin{array}{c}\text { I_J for } \\
\text { Strep. spp. }\end{array}$ & $\begin{array}{l}\text { I_J for } \\
\text { E. coli }\end{array}$ & $\begin{array}{c}\text { I_J for } \\
\text { Staph. aureus }\end{array}$ & $\begin{array}{l}\text { I_J for } \\
\text { Strep. spp. }\end{array}$ & $\begin{array}{l}\text { I_J for } \\
\text { E. coli }\end{array}$ & $\begin{array}{c}\text { I_J for } \\
\text { Staph. aureus }\end{array}$ & $\begin{array}{l}\text { I_J for } \\
\text { Strep. spp. }\end{array}$ & $\begin{array}{l}\mathrm{I}_{-} \mathrm{J} \text { for } \\
\text { E. coli }\end{array}$ & $\begin{array}{c}\text { I_J for } \\
\text { Staph. aureus }\end{array}$ \\
\hline 1 & 0 & 0 & 0 & 0 & $1 \_-3$ & 0 & $1 \_-3$ & $1 \_-3$ & 0 & 0 & $1_{-}-2$ & 0 \\
\hline 2 & 0 & 0 & 0 & 0 & $1 \_-3$ & 0 & $1 \_-3$ & $1 \_-3$ & 0 & 0 & $1_{-}-1$ & 0 \\
\hline 3 & 0 & 0 & 0 & 0 & $1 \_-3$ & 0 & $1 \_-2$ & $1 \_-2$ & 0 & 0 & 1_1 & 0 \\
\hline 4 & 0 & 0 & 0 & 0 & $11_{-}-3$ & 0 & $1 \_-1$ & $1 \_-1$ & 0 & 0 & 1_2 & 0 \\
\hline 5 & 0 & 0 & 0 & 0 & $1 \_-3$ & 0 & 1_1 & 1_1 & 0 & 0 & 1_3 & 0 \\
\hline 6 & 0 & 0 & 0 & 0 & $1 \_-3$ & 0 & $1 \_2$ & $1 \_2$ & 0 & 0 & 1_4 & 0 \\
\hline 7 & 0 & 0 & 0 & 0 & $1 \_-2$ & 0 & $1 \_3$ & $1 \_3$ & 0 & 0 & $1 \_5$ & 0 \\
\hline 8 & 0 & 0 & 0 & 0 & $1 \_-1$ & 0 & $1 \_4$ & $1 \_4$ & 0 & 0 & $1 \_6$ & 0 \\
\hline 9 & 0 & 0 & 0 & 0 & 1_1 & 0 & $2 \_1$ & 0 & 0 & 0 & $1 \_7$ & 0 \\
\hline 10 & 0 & 0 & 0 & 0 & $1 \_2$ & 0 & $2 \_2$ & 0 & 0 & 0 & $1 \_8$ & 0 \\
\hline 11 & 0 & 0 & 0 & 0 & $1 \_3$ & 0 & $2 \_3$ & 0 & 0 & 0 & 1_9 & 0 \\
\hline 12 & 0 & 0 & 0 & 0 & 1_4 & 0 & 2_4 & 0 & 0 & 0 & 0 & $2 \_1$ \\
\hline 13 & 0 & 0 & 0 & 0 & $1 \_5$ & 0 & $2 \_5$ & 0 & 0 & 0 & 0 & $2 \_2$ \\
\hline 14 & 0 & 0 & 0 & 0 & 1_6 & 0 & $2 \_6$ & 0 & 0 & 0 & 0 & $2 \_3$ \\
\hline 15 & 0 & 0 & 0 & 0 & $1 \_7$ & 0 & $2 \_7$ & 0 & 0 & 0 & 0 & $2 \_4$ \\
\hline 16 & 0 & 0 & 0 & 0 & 1_8 & 0 & $2 \_8$ & 0 & 0 & 3_1 & 0 & 0 \\
\hline 17 & 0 & 0 & 0 & 0 & 1_9 & 0 & $2 \_9$ & 0 & 0 & 3_2 & 0 & 0 \\
\hline 18 & 0 & 0 & 0 & 0 & 1_9 & 0 & 2_9 & 0 & 0 & 3_3 & 0 & 0 \\
\hline 19 & 0 & 0 & 0 & 0 & 1_9 & 0 & 2_9 & 0 & 0 & 3_4 & 0 & 0 \\
\hline 20 & 0 & 0 & 0 & 0 & 1_9 & 0 & $2 \_9$ & 0 & 0 & $3 \_5$ & 0 & 0 \\
\hline 21 & 0 & 0 & 0 & 0 & 1_9 & 0 & 2_9 & 0 & 0 & 3_6 & 0 & 0 \\
\hline 22 & 0 & 0 & 0 & 0 & 1_9 & 0 & 2_9 & 0 & 0 & $3 \_7$ & 0 & 0 \\
\hline 23 & 0 & 0 & 0 & 0 & 1_9 & 0 & 2_9 & 0 & 0 & $3 \_8$ & 0 & 0 \\
\hline 24 & 0 & 0 & 0 & 0 & 1_9 & 0 & $2 \_9$ & 0 & 0 & 3_9 & 0 & 0 \\
\hline 25 & 0 & 0 & 0 & 0 & 1_9 & 0 & $2 \_9$ & 0 & 0 & 3_9 & 0 & 0 \\
\hline
\end{tabular}

فำ 1 did not have clinical mastitis (CM); cow 2 had one CM case (E. coli in wk 9 of lactation); cow 3 had E. coli in wk 5 and Strep. spp. twice (in wk 5 and 9 ); and cow 4 had 3 CM cases (E. coli in wk 3; Staph. aureus in wk 12; and Strep. spp. in wk 16).

The index variables I_J (I = first, second, or third occurrence of CM; J = number of weeks before or after that occurrence of CM) indicate when milk weights were measured in ₹. relation to occurrence of a specific type of $\mathrm{CM}$; for example, $0=$ free of that type of CM; $1 \_-3=\geq 3$ wk before first CM; $1 \_-2=2$ wk before first CM; $1 \_-1=1$ wk before first œ $\mathrm{CM} ; 1 \_1=$ week of first CM occurrence; $1 \_2=$ second week after first CM occurrence $\ldots .1 \_9=\geq 9$ wk after first CM occurrence; $2 \_1=$ week of second CM occurrence; $2 \_2=$ second week after second CM occurrence . . $2 \_9=\geq 9$ wk after second CM occurrence; $3 \_1=$ week of third CM occurrence; $3 \_2=$ second week after third CM occurrence ... $3 \_9=\geq 9$ wk after third CM occurrence. 
Table 2. Distribution of clinical mastitis (CM) cases and pathogens in 5 New York State herds from 2004 to $2011^{1}$

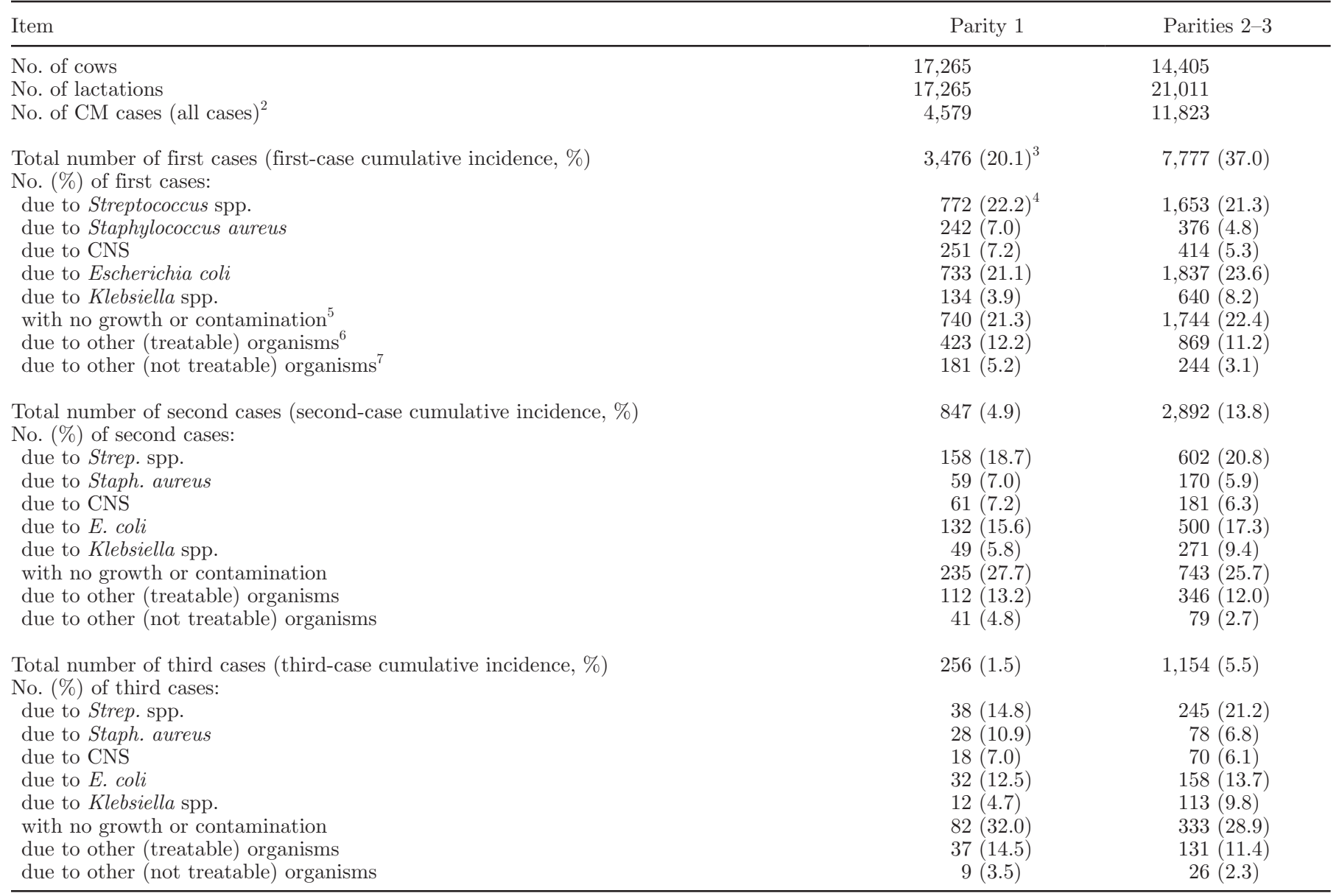

${ }^{1}$ Parity 1: CM cases occurring in wk 1-48 of lactation; parities 2-3: CM cases occurring in wk 1-44 of lactation. These time intervals reflect the number of weeks cows were followed in the mixed models (Tables 3-6).

${ }^{2}$ Comprises first, second, and third CM cases occurring in a lactation.

${ }^{3}$ Calculated as $3,476 / 17,265=20.1 \%$; that is, $20.1 \%$ of parity 1 cows had at least $1 \mathrm{CM}$ case.

${ }^{4}$ Calculated as $772 / 3,476=22.2 \%$.

${ }^{5}$ Comprises cases with CM signs but no bacterial growth (above the level that could be detected from our microbiological procedures) observed in the culture sample, and cases with contamination ( $\geq 3$ pathogens in sample).

"Other Treatable" group includes CM due to Citrobacter, Corynebacterium bovis, Enterobacter, Enterococcus, Pasteurella, Pseudomonas, or others.

7"Other Not Treatable" group includes CM due to Trueperella pyogenes, Mycoplasma, Prototheca, or yeast.

any type) in the first 62 wk of a lactation. The hazard increased with each successive case, particularly between the first and second cases. Figure 2 shows the survivor function for the first $3 \mathrm{E}$. coli $\mathrm{CM}$ cases in the first 62 wk of a lactation. As with all CM cases (Figure 1), the hazard increased with each successive case. The $95 \%$ confidence intervals are also shown in each figure. In Figure 1, there is no overlap between cases. In Figure 2, however, the upper CI for a third case of $E$. coli overlaps, to a small extent, with part of the survivor function for a second case of E. coli.

\section{Effects of Pathogens on Milk Yield}

Tables 3, 4, 5, and 6 show the parameter estimates and $95 \%$ CI for each case and pathogen, for primiparas and multiparas. Although the estimates are displayed in separate tables, they all originate from the same model (one model for each parity group).

In both parity groups, cows that had Streptococcus spp., Staph. aureus, CNS, E. coli, Klebsiella spp., or no growth/contamination in their first case were higher producers before CM onset compared with their nonCM herdmates (Tables $3-5$ ). 


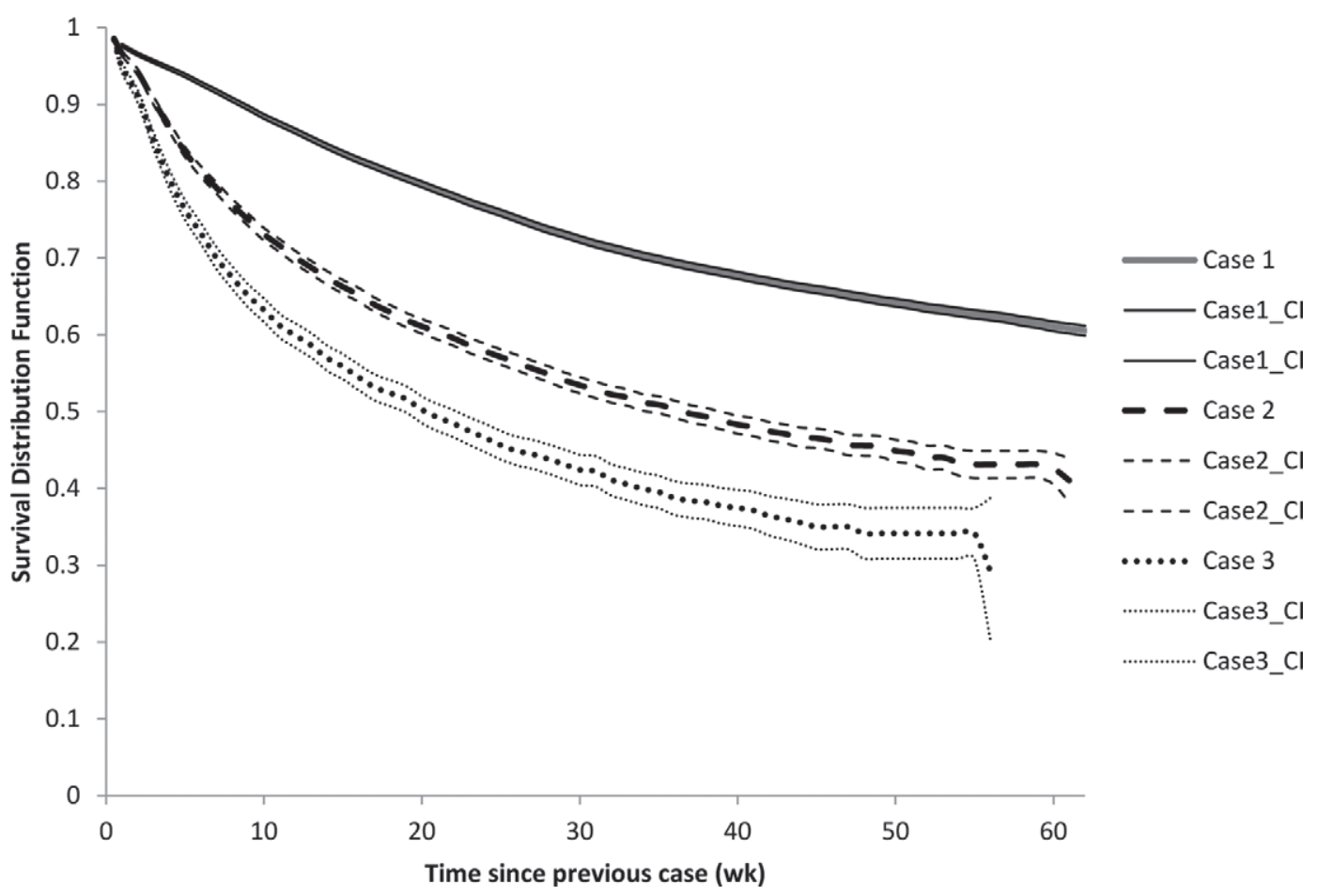

Figure 1. Survivor function for the first 3 clinical mastitis (CM) cases (of any type) in a lactation, of 45,333 lactations in 21,731 cows in 5 New York State herds, followed for up to $62 \mathrm{wk}$ of lactation. The $\mathrm{x}$-axis indicates weeks since calving for the first case or weeks since last CM for subsequent cases; 95\% CI (Case1_CI, Case2_CI, Case3_CI) are also shown.

In primiparas, milk losses became apparent in the week before diagnosis of Streptococcus spp. (Table 3), Staph. aureus (Table 4), or "other not treatable" (Table 6; several weeks before diagnosis) CM. For E. coli (Table 5), Klebsiella spp. (Table 5), no growth/contamination (Table 3), and "other treatable" pathogens (Table 6), milk losses began during the week of diagnosis of the first case of CM. For all pathogens except CNS, milk losses occurred for several weeks following diagnosis. Production also declined upon occurrence of second and third cases, although patterns of loss varied with pathogen. Milk losses tended to decrease with time since diagnosis. Milk loss was not associated with occurrence of CNS CM (Table 4).

In multiparas, milk losses began to occur in the week before diagnosis of "other not treatable" pathogens (Table 6). For all other pathogens except CNS, which had no effect on milk production, milk losses began in the week of diagnosis of the first case of CM (Tables 3-6). For all pathogens except CNS, milk losses occurred for several weeks following diagnosis. Subsequent cases were also associated with a decrease in production; patterns of loss varied with pathogen. Milk losses tended to taper off with time since diagnosis. No decline in milk production was observed when CNS was the first or third case of lactation; however, when it was the second-occurring case, some milk loss was observed for several weeks afterward (Table 4). When the third case was due to an "other treatable" pathogen, milk losses were trivial after the week of diagnosis (Table 6).

In summary, overall milk losses associated with Streptococcus spp. and "other treatable pathogens" were similar in both parity groups. Losses associated with CM due to "other not treatable" pathogens were higher in primiparas than in multiparas. Losses tended to be higher in multiparas than in primiparas for $E$. coli, Klebsiella spp., and CM with no growth/contamination. When Staph. aureus was the first CM case, losses were greater in primiparas. Coagulase-negative staphylococcus CM was not associated with milk loss in either parity group, except when it occurred as the second case in multiparas; even then, losses were generally less than $2 \mathrm{~kg} / \mathrm{d}$.

Figures $3 \mathrm{~A}, 3 \mathrm{~B}$, and $3 \mathrm{C}$ show the predicted lactation curves for 4 hypothetical parity-2 cows, one without $\mathrm{CM}$ (in all figures), and the others with 3 cases of CM [3 cases of E. coli (Figure 3A); Streptococcus spp., 2 cases of E. coli (Figure 3B); Streptococcus spp., CM with no growth, E. coli (Figure 3C)] in lactation. They were plotted using the relevant estimates from slightly different models (these contained only factors for the CM types of interest; i.e., E. coli, Streptococcus spp., 


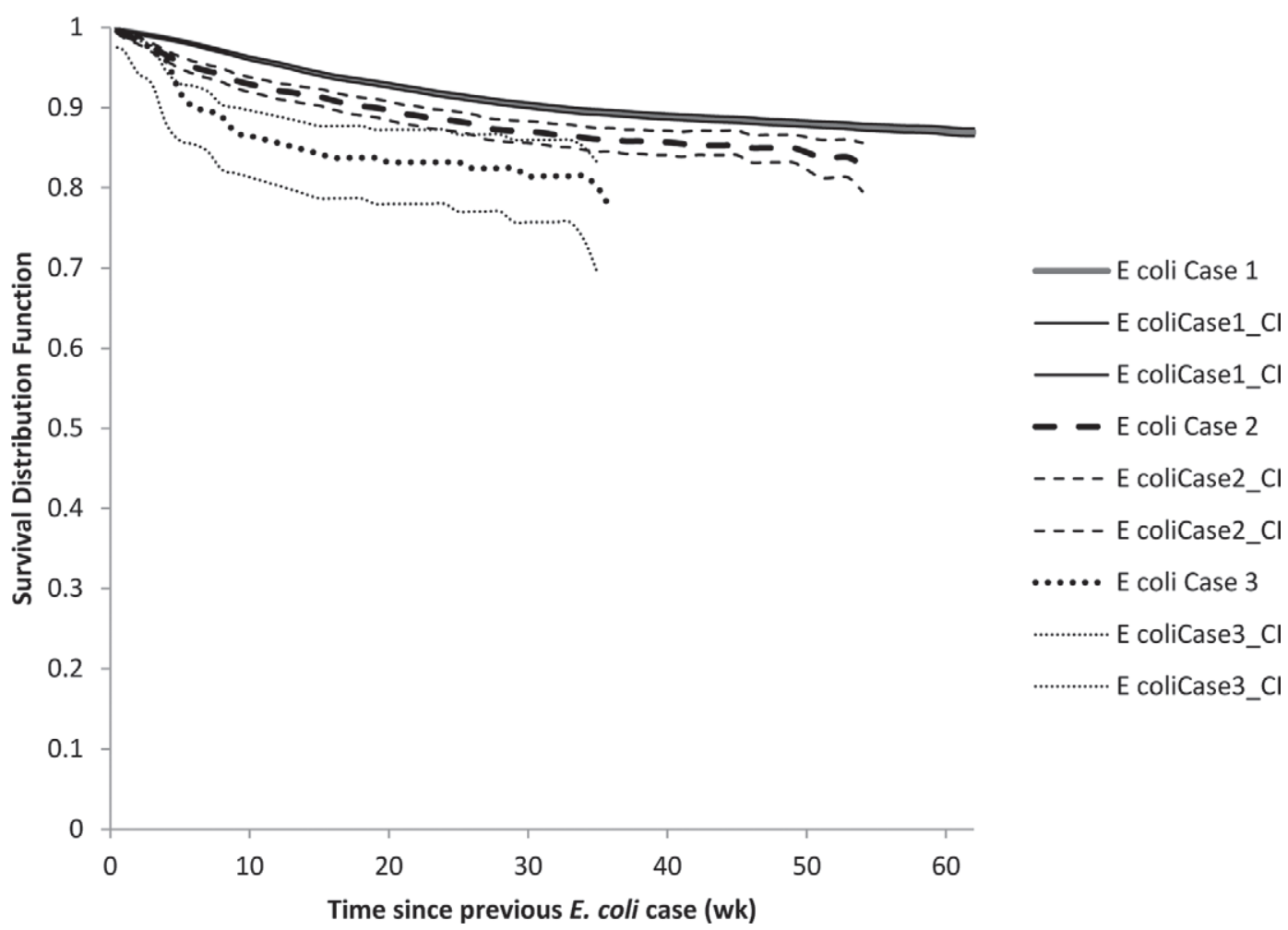

Figure 2. Survivor function for the first 3 Escherichia coli 3 clinical mastitis (CM) cases in a lactation, of 38,787 lactations in 19,537 cows in 5 New York State herds, followed for up to 62 wk of lactation. The x-axis indicates weeks since calving for the first case or weeks since last CM for subsequent cases; 95\% confidence intervals (E coliCase1_CI, E coliCase2_CI, E coliCase3_CI) are also shown.

no growth) for multiparous cows than the estimates from the full models in Tables 3 and 5 . All 3 CM cows experienced a sharp decrease in milk yield at the time of diagnosis of each case. The extent of recovery to normal production varied with pathogen. The cow with 2 noncoliform cases (Streptococcus spp. and no growth) showed a severe production loss after the third CM case (caused by E. coli). The cow with a Streptococcus spp. CM case followed by 2 cases of $E$. coli showed a similar milk loss for each $E$. coli case and continued to lose milk long after the third case. The cow with 3 cases of $E$. coli showed equal severity across all 3 cases of $\mathrm{CM}$ and eventually returned to a production level close to that of unaffected herdmates.

Figures $4 \mathrm{~A}, 4 \mathrm{~B}$, and $4 \mathrm{C}$ show the predicted lactation curves for 4 hypothetical parity-2 cows, one without $\mathrm{CM}$ (in all figures) and the other 3 with 1 (Figure 4A), 2 (Figure 4B), or 3 (Figure 4C) cases of Klebsiella spp. CM in lactation. They were plotted using the relevant estimates from a model containing parity, week of lactation, calving season, indices for Klebsiella spp. CM, and other diseases. Cows with only one case of Klebsiella spp. CM did not return to pre-CM milk production but did return to milk production levels of unaffected herdmates several weeks after the CM case.
Cows with more than one case, however, continued to lose milk, even relative to unaffected herdmates, for the remainder of lactation.

For primiparas, if the second case had the same pathogen as the first case, the cow lost $3.1 \mathrm{~kg} / \mathrm{d}$ of milk (95\% CI: 2.6, 3.7); if the pathogens were different, she lost $2.7 \mathrm{~kg} / \mathrm{d}$ of milk (95\% CI: $2.2,3.1)$. If the third case had the same pathogen as the second case, the cow gained $2.0 \mathrm{~kg} / \mathrm{d}$ of milk (95\% CI: $1.3,2.7)$; if the pathogens were different, she gained $0.7 \mathrm{~kg} / \mathrm{d}(95 \% \mathrm{CI}$ : $0.1,1.3)$.

For multiparas, if the second case had the same pathogen as the first case, the cow lost $1.5 \mathrm{~kg} / \mathrm{d}$ of milk (95\% CI: 1.1, 2.0); if the pathogens were different, she lost $1.7 \mathrm{~kg} / \mathrm{d}$ of milk $(95 \% \mathrm{CI}: 1.3,2.0)$. If the third case had the same pathogen as the second case, the cow gained $1.1 \mathrm{~kg} / \mathrm{d}$ of milk (95\% CI: $0.5,1.6)$; if the pathogens were different, she gained $0.6 \mathrm{~kg} / \mathrm{d}(95 \% \mathrm{CI}$ : $0.1,1.0)$.

\section{DISCUSSION}

Decreases in milk production were associated with CM caused by a variety of pathogens, although milk loss patterns varied by pathogen and case number. In 
Table 3. Effects $(\mathrm{kg} / \mathrm{d})$ of up to 3 repeated clinical mastitis $(\mathrm{CM})$ cases with Streptococcus spp. detected and CM cases showing no important growth, or showing contamination, on milk yield in parity 1 (17,265 lactations) and parities 2-3 (21,011 lactations) (estimated separately) on 5 New York State dairy farms from 2004 to $2011^{1}$

\begin{tabular}{|c|c|c|c|c|c|c|c|c|}
\hline \multirow[b]{2}{*}{ Time $^{2}$} & \multicolumn{4}{|c|}{ Streptococcus spp. } & \multicolumn{4}{|c|}{ No important growth/contamination ${ }^{3}$} \\
\hline & Estimate & $95 \% \mathrm{CI}$ & Estimate & $95 \% \mathrm{CI}$ & Estimate & $95 \% \mathrm{CI}$ & Estimate & $95 \% \mathrm{CI}$ \\
\hline $\begin{array}{l}3 \text { wk before first CM case } \\
2 \text { wk before } \\
1 \text { wk before } \\
\text { Week of first CM case } \\
2 \text { wk after first case } \\
+3 \mathrm{wk} \\
+4 \mathrm{wk} \\
+5 \mathrm{wk} \\
+6 \mathrm{wk} \\
+7 \mathrm{wk} \\
+8 \mathrm{wk} \\
+\geq 9 \mathrm{wk} \\
\text { Week of second CM case }{ }^{5} \\
2 \mathrm{wk} \text { after second case } \\
+3 \mathrm{wk} \\
+4 \mathrm{wk} \\
+5 \mathrm{wk} \\
+6 \mathrm{wk} \\
+7 \mathrm{wk} \\
+8 \mathrm{wk} \\
+\geq 9 \mathrm{wk} \\
\text { Week of third CM case } \\
2 \text { wk after third case } \\
+3 \mathrm{wk} \\
+4 \mathrm{wk} \\
+5 \mathrm{wk} \\
+6 \mathrm{wk} \\
+7 \mathrm{wk} \\
+8 \mathrm{wk} \\
+\geq 9 \mathrm{wk} \\
\end{array}$ & $\begin{array}{l}1.0^{*} \\
0.8^{*} \\
-0.8^{*} \\
-3.7^{*} \\
-3.3^{*} \\
-2.6^{*} \\
-2.0^{*} \\
-1.3^{*} \\
-1.2^{*} \\
-1.0^{*} \\
-1.0^{*} \\
-0.7^{*} \\
-3.4^{*} \\
-3.4^{*} \\
-2.3^{*} \\
-2.2^{*} \\
-2.1^{*} \\
-1.8^{*} \\
-2.1^{*} \\
-1.2^{*} \\
-1.1^{*} \\
-2.3^{*} \\
-3.1^{*} \\
-3.8^{*} \\
-3.6^{*} \\
-2.7^{*} \\
-2.5^{*} \\
-1.8^{2} \\
-0.7 \\
0.2 \\
\end{array}$ & $\begin{array}{c}0.7,1.2 \\
0.4,1.1 \\
-1.1,-0.4 \\
-4.1,-3.3 \\
-3.7,-2.8 \\
-3.0,-2.1 \\
-2.5,-1.6 \\
-1.8,-0.9 \\
-1.6,-0.8 \\
-1.5,-0.6 \\
-1.4,-0.6 \\
-1.1,-0.4 \\
-4.0,-2.8 \\
-4.1,-2.6 \\
-3.1,-1.4 \\
-3.1,-1.3 \\
-3.0,-1.1 \\
-2.8,-0.8 \\
-3.1,-1.1 \\
-2.1,-0.2 \\
-1.9,-0.2 \\
-3.4,-1.2 \\
-4.6,-1.6 \\
-5.5,-2.0 \\
-5.5,-1.6 \\
-4.8,-0.6 \\
-4.6,-0.5 \\
-4.0,0.3 \\
-2.7,1.3 \\
-1.5,1.8 \\
\end{array}$ & $\begin{array}{l}1.6^{*} \\
1.4^{*} \\
0.4^{*} \\
-3.7^{*} \\
-4.0^{*} \\
-2.5^{*} \\
-1.9^{*} \\
-1.1^{*} \\
-1.0^{*} \\
-0.6^{*} \\
-0.5^{*} \\
-0.2 \\
-3.1^{*} \\
-3.6^{*} \\
-2.0^{*} \\
-1.5^{*} \\
-0.9^{*} \\
-0.8^{*} \\
-0.3 \\
-0.3 \\
-0.2 \\
-3.6^{*} \\
-3.3^{*} \\
-2.2^{*} \\
-1.5^{*} \\
-1.2^{*} \\
-1.6^{*} \\
-1.5^{*} \\
-0.9 \\
-0.2 \\
\end{array}$ & $\begin{array}{l}1.4,1.9 \\
1.1,1.7 \\
0.1,0.7 \\
-4.0,-3.3 \\
-4.3,-3.6 \\
-2.9,-2.1 \\
-2.3,-1.5 \\
-1.5,-0.7 \\
-1.4,-0.6 \\
-1.0,-0.2 \\
-0.8,-0.1 \\
-0.5,0.1 \\
-3.5,-2.7 \\
-4.0,-3.1 \\
-2.5,-1.4 \\
-2.1,-0.9 \\
-1.5,-0.3 \\
-1.4,-0.1 \\
-1.0,0.3 \\
-1.0,0.4 \\
-0.8,0.4 \\
-4.2,-3.0 \\
-4.1,-2.5 \\
-3.1,-1.3 \\
-2.5,-0.6 \\
-2.2,-0.2 \\
-2.6,-0.6 \\
-2.4,-0.5 \\
-1.8,0.1 \\
-1.0,0.6 \\
\end{array}$ & $\begin{array}{r}1.4^{*} \\
1.1^{*} \\
0.6^{*} \\
-1.2^{*} \\
-1.1^{*} \\
-1.1^{*} \\
-1.0^{*} \\
-0.9^{*} \\
-1.0^{*} \\
-1.1^{*} \\
-1.0^{*} \\
-0.8^{*} \\
-3.0^{*} \\
-2.2^{*} \\
-1.7^{*} \\
-1.4^{*} \\
-1.4^{*} \\
-1.3^{*} \\
-1.3^{*} \\
-1.6^{*} \\
-1.3^{*} \\
-2.6^{*} \\
-2.7^{*} \\
-2.2^{*} \\
-1.3^{*} \\
-0.6 \\
-0.4 \\
-0.8^{2} \\
0.1 \\
\end{array}$ & $\begin{array}{c}1.1,1.6 \\
0.7,1.4 \\
0.2,1.0 \\
-1.6,-0.8 \\
-1.6,-0.7 \\
-1.5,-0.6 \\
-1.4,-0.5 \\
-1.3,-0.4 \\
-1.5,-0.6 \\
-1.5,-0.6 \\
-1.4,-0.6 \\
-1.1,-0.5 \\
-3.4,-2.5 \\
-2.8,-1.7 \\
-2.4,-1.1 \\
-2.1,-0.7 \\
-2.1,-0.6 \\
-2.0,-0.5 \\
-2.1,-0.5 \\
-2.4,-0.9 \\
-1.9,-0.7 \\
-3.4,-1.8 \\
-3.7,-1.6 \\
-3.4,-1.1 \\
-2.6,-0.1 \\
-1.9,0.7 \\
-1.8,0.9 \\
-2.1,0.5 \\
-1.2,1.3 \\
-0.3,1.7 \\
\end{array}$ & $\begin{array}{l}1.5^{*} \\
1.2^{*} \\
0.5^{*} \\
-2.3^{*} \\
-2.2^{*} \\
-1.5^{*} \\
-1.0^{*} \\
-0.7^{*} \\
-0.3 \\
-0.2 \\
-0.1 \\
0.3^{*} \\
-3.8^{*} \\
-3.8^{*} \\
-2.3^{*} \\
-1.8^{*} \\
-1.5^{*} \\
-1.3^{*} \\
-0.8^{*} \\
-0.5 \\
-0.0 \\
-4.2^{*} \\
-3.8^{*} \\
-3.3^{*} \\
-2.3^{*} \\
-1.9^{*} \\
-2.0^{*} \\
-1.6^{*} \\
-0.9^{*} \\
-0.6 \\
\end{array}$ & $\begin{array}{l}1.3,1.7 \\
0.9,1.5 \\
0.1,0.8 \\
-2.7,-2.0 \\
-2.5,-1.8 \\
-1.9,-1.1 \\
-1.3,-0.6 \\
-1.1,-0.3 \\
-0.7,0.0 \\
-0.5,0.2 \\
-0.5,0.3 \\
-0.0,0.6 \\
-4.1,-3.4 \\
-4.2,-3.3 \\
-2.8,-1.9 \\
-2.4,-1.3 \\
-2.1,-1.0 \\
-1.9,-0.8 \\
-1.4,-0.2 \\
-1.0,0.1 \\
-0.5,0.5 \\
-4.8,-3.7 \\
-4.5,-3.1 \\
-4.1,-2.5 \\
-3.1,-1.5 \\
-2.8,-1.1 \\
-2.9,-1.2 \\
-2.4,-0.8 \\
-1.7,-0.1 \\
-1.2,0.1 \\
\end{array}$ \\
\hline
\end{tabular}

${ }^{1} \mathrm{~A}$ positive value indicates a gain in milk yield in that week; a negative value indicates a loss. Parity 1 cows were followed for up to 48 wk of lactation; parities 2-3 were followed for up to $44 \mathrm{wk}$ of lactation. The estimates are from mixed models including factors for parity, calving season, week-in-milk, several types of CM [Strep. spp., Staphylococcus aureus, CNS, Escherichia coli, Klebsiella spp., no important growth/contamination (cases with CM signs but no bacterial growth observed in the culture sample) and cases with contamination ( $\geq 3$ pathogens in sample), other treatable organisms (includes CM due to Citrobacter, Corynebacterium bovis, Enterobacter, Enterococcus, Pasteurella, Pseudomonas, or others), and other not-treatable organisms (includes CM due to Trueperella pyogenes, Mycoplasma, Prototheca, or yeast)], and other non-CM diseases (milk fever, retained placenta, metritis, ketosis, displaced abomasum). The reference category comprised cows not experiencing that type of CM (i.e., Strep. spp. CM or CM with no important growth/contamination) in a given lactation.

${ }^{2}$ Time of milk measurement in relation to $\mathrm{CM}$ occurrence.

${ }^{3}$ Comprises cases with CM signs but no bacterial growth (above the level that could be detected from our microbiological procedures) observed in the culture sample, and cases with contamination ( $\geq 3$ pathogens in sample).

${ }^{4}$ The first CM case is due to, for example, Strep. spp.; second and third cases could be due to any pathogen, not necessarily Strep. spp.

${ }^{5}$ The second CM case is due to, for example, Strep. spp.; first and third cases could be due to any pathogen, not necessarily Strep. spp.

${ }^{6}$ The third CM case is due to, for example, Strep. spp.; first and second cases could be due to any pathogen, not necessarily Strep. spp. $* P<0.05$.

both parity groups, cows that went on to contract most types of $\mathrm{CM}$ were higher producers before $\mathrm{CM}$ onset than were their non-CM herdmates, suggesting that they would have produced even more milk had they not contracted CM. This has been previously observed (Gröhn et al., 2004; Hagnestam et al., 2007; Ericsson Unnerstad et al., 2009). Our study accounted only for actual losses in production in the cow. It did not account for milk produced that was withheld due to antibiotic treatment.
The differing patterns of milk loss observed in this study may be related to the course and intensity of the pathogen-specific inflammatory response to IMI. For example, high levels of bacteria during a transient infection period are commonly associated with a more severe inflammatory response and are often seen with E. coli; persistent infection with low levels of bacteria and a more gentle inflammatory response is more typically associated with Staph. aureus; and a long period of infection with high levels of bacteria and with persis- 
Table 4. Effects $(\mathrm{kg} / \mathrm{d})$ of up to 3 repeated clinical mastitis (CM) cases with Staphylococcus aureus detected and CNS detected on milk yield in parity 1 (17,265 lactations) and parities 2-3 (21,011 lactations) (estimated separately) on 5 New York State dairy farms from 2004 to $2011^{1}$

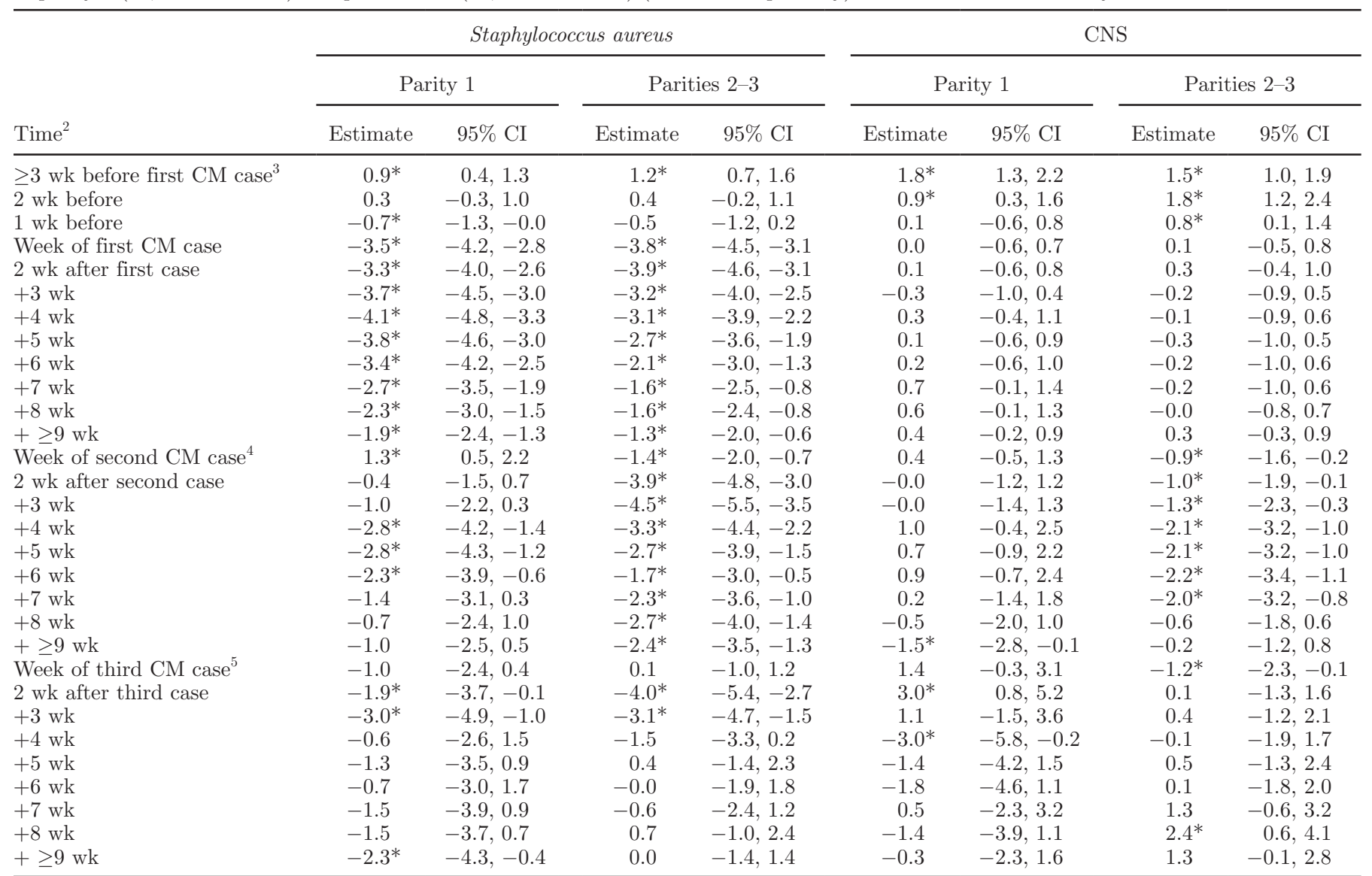

${ }^{1} \mathrm{~A}$ positive value indicates a gain in milk yield in that week; a negative value indicates a loss. Parity 1 cows were followed for up to 48 wk of lactation; parities 2-3 were followed for up to $44 \mathrm{wk}$ of lactation. The estimates are from mixed models including factors for parity, calving season, week-in-milk, several types of CM [Strep. spp., Staphylococcus aureus, CNS, Escherichia coli, Klebsiella spp., no important growth/contamination (cases with CM signs but no bacterial growth observed in the culture sample) and cases with contamination ( $>3$ pathogens in sample), other treatable organisms (includes CM due to Citrobacter, Corynebacterium bovis, Enterobacter, Enterococcus, Pasteurella, Pseudomonas, or others), and other not-treatable organisms (includes CM due to Trueperella pyogenes, Mycoplasma, Prototheca, or yeast)], and other non-CM diseases (milk fever, retained placenta, metritis, ketosis, displaced abomasum). The reference category comprised cows not experiencing that type of CM (i.e., Staph. aureus or CNS) in a given lactation.

${ }^{2}$ Time of milk measurement in relation to CM occurrence.

${ }^{3}$ The first CM case is due to, for example, Staph. aureus; second and third cases could be due to any pathogen, not necessarily Staph. aureus.

${ }^{4}$ The second CM case is due to, for example, Staph. aureus; first and third cases could be due to any pathogen, not necessarily Staph. aureus.

${ }^{5}$ The third CM case is due to, for example, Staph. aureus; first and second cases could be due to any pathogen, not necessarily Staph. aureus.

$* P<0.05$.

tent high levels of SCC in milk is associated with Strep. uberis (Schukken et al., 2011). In a review paper, Zhao and Lacasse (2008) stated that Staph. aureus damages secretory tissue in the mammary gland, which is subsequently replaced by nonsecretory tissue, thereby reducing the cow's overall milk production ability. Escherichia coli has a different mechanism of action, causing acute inflammation that generally takes place in the alveoli itself, resulting in less permanent damage to the mammary tissue.

Our data were collected on large, well-managed dairy farms with good disease detection, a high level of milk production, and 3-times-a-day milking. As always with these types of studies, there is a trade-off between random sampling of herds and the quality of the obtained data. We have followed these herds with high quality data for approximately $10 \mathrm{yr}$. The observations from this cohort are presumed to be biologically valid due to the precision of the data. The exact ability to generalize these data to all farms is of course unknown, and when interpreting the results of these data this should be kept in mind.

Staphylococcus aureus CM was associated with lower milk production when it occurred as the first or second 
Table 5. Effects (kg/d) of up to 3 repeated clinical mastitis (CM) cases with Escherichia coli detected and Klebsiella spp. detected on milk yield in parity 1 (17,265 lactations) and parities 2-3 (21,011 lactations) (estimated separately) on 5 New York State dairy farms from 2004 to $2011^{1}$

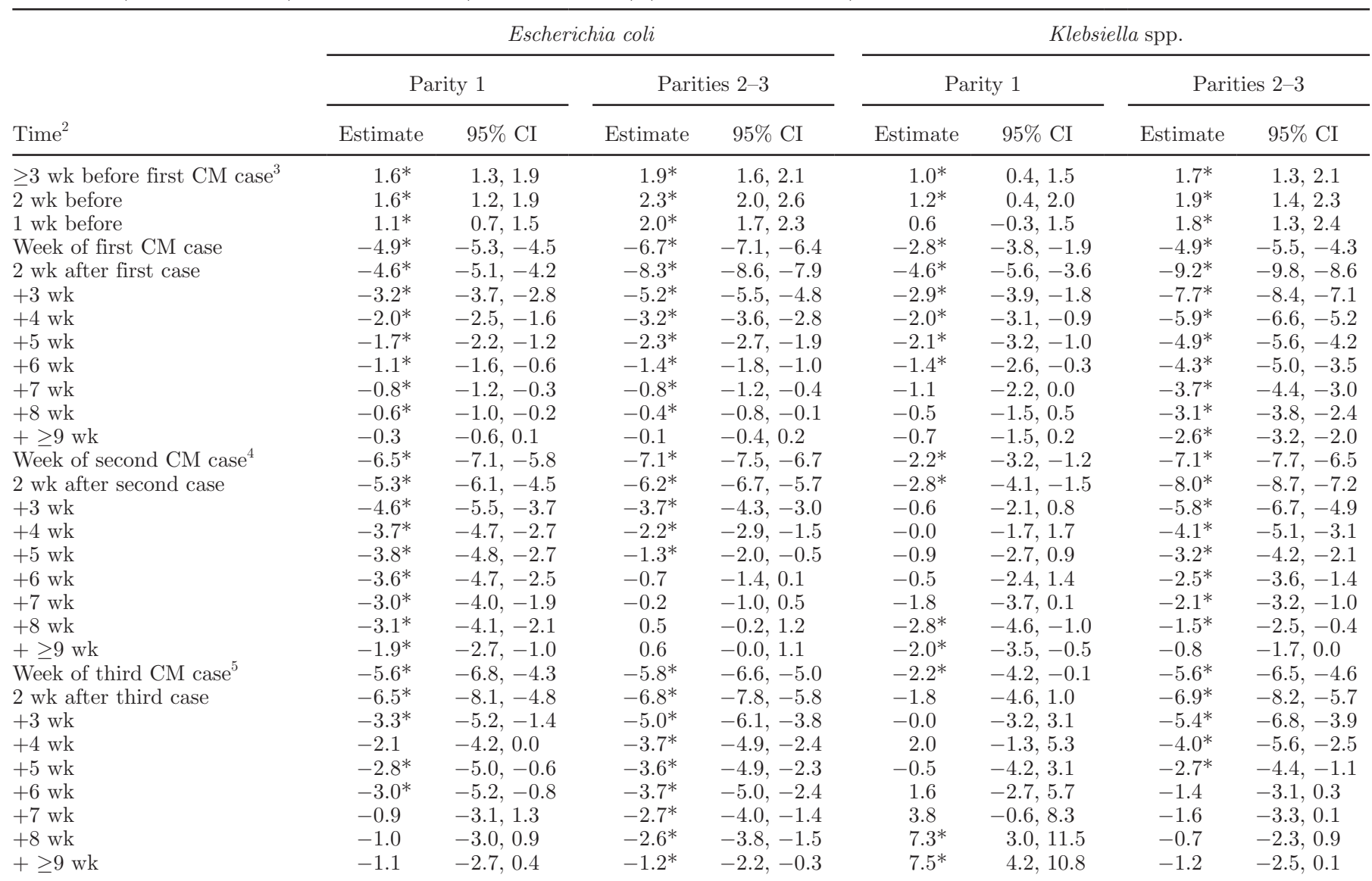

${ }^{1}$ A positive value indicates a gain in milk yield in that week; a negative value indicates a loss. Parity 1 cows were followed for up to 48 wk of lactation; parities 2-3 were followed for up to 44 wk of lactation. The estimates are from mixed models including factors for parity, calving season, week-in-milk, several types of CM [Strep. spp., Staphylococcus aureus, CNS, Escherichia coli, Klebsiella spp., no important growth/contamination (cases with CM signs but no bacterial growth observed in the culture sample) and cases with contamination ( $>3$ pathogens in sample), other treatable organisms (includes CM due to Citrobacter, Corynebacterium bovis, Enterobacter, Enterococcus, Pasteurella, Pseudomonas, or others), and other not-treatable organisms (includes CM due to Trueperella pyogenes, Mycoplasma, Prototheca, or yeast)], and other non-CM diseases (milk fever, retained placenta, metritis, ketosis, displaced abomasum). The reference category comprised cows not experiencing that type of CM (i.e., E. coli or Klebsiella spp.) in a given lactation.

${ }^{2}$ Time of milk measurement in relation to $\mathrm{CM}$ occurrence.

${ }^{3}$ The first CM case is due to, for example, E. coli; second and third cases could be due to any pathogen, not necessarily $E$. coli. ${ }^{4}$ The second $\mathrm{CM}$ case is due to, for example, E. coli; first and third cases could be due to any pathogen, not necessarily $E$. coli. ${ }^{5}$ The third CM case is due to, for example, E. coli; first and second cases could be due to any pathogen, not necessarily E. coli. $* P<0.05$.

case in lactation, but less so when it was the third case. Reksen et al. (2007) reported that mastitis due to Staph. aureus was associated with lower milk production in Norwegian cows of first parity and cows in third or higher parity, and to a lesser extent in cows of second parity.

The only category of pathogens in our study to have no or little detrimental effect on milk production was the CNS group. This has been observed before, with some researchers even reporting higher production following its occurrence (Piepers et al., 2013). In 4,200 herds in the northeastern United States over a 15-yr period, cows with subclinical CNS IMI produced more milk than did culture-negative cows; the increase was small but statistically significant (Schukken et al., 2009a). In a Flemish study, Piepers et al. (2010) found that heifers with a subclinical CNS infection in the first week of lactation out-produced their uninfected herdmates by 2.9 $\mathrm{kg}$ milk/d over the lactation. New Zealand heifers with a subclinical IMI caused by minor pathogens (including CNS) produced $0.7 \mathrm{~kg} / \mathrm{d}$ more milk throughout lactation than did uninfected heifers (Compton et al., 2007). It may be hypothesized that a current infection with a minor pathogen prevents a subsequent infection with a 
Table 6. Effects $(\mathrm{kg} / \mathrm{d})$ of up to 3 repeated clinical mastitis $(\mathrm{CM})$ cases with an "other treatable" pathogen detected and an "other nottreatable" pathogen detected on milk yield in parity 1 (17,265 lactations) and parities 2-3 (21,011 lactations) (estimated separately) on 5 New York State dairy farms from 2004 to $2011^{1}$

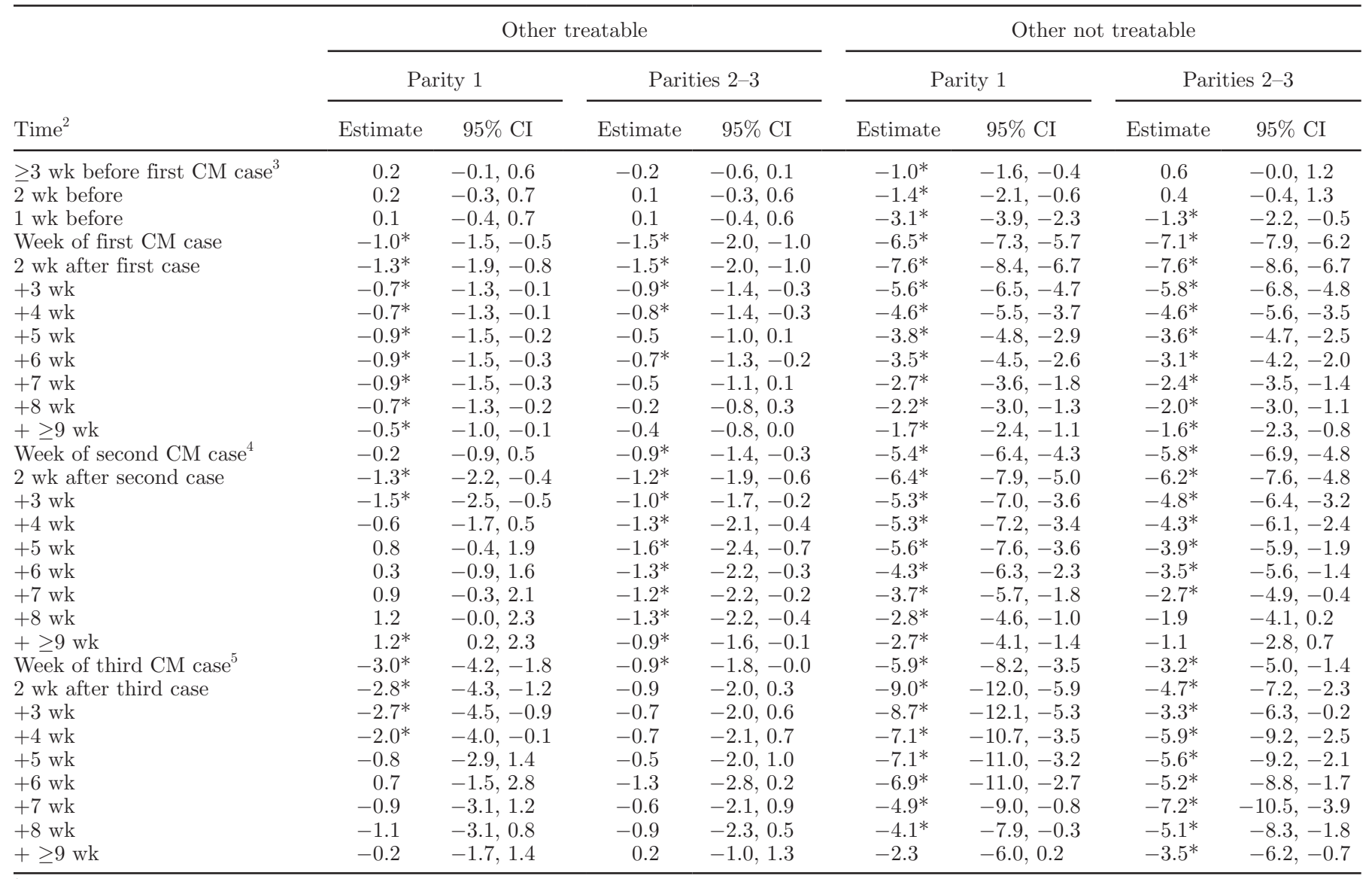

${ }^{1}$ A positive value indicates a gain in milk yield in that week; a negative value indicates a loss. Parity 1 cows were followed for up to 48 wk of lactation; parities 2-3 were followed for up to $44 \mathrm{wk}$ of lactation. The estimates are from mixed models including factors for parity, calving season, week-in-milk, several types of CM [Strep. spp., Staphylococcus aureus, CNS, Escherichia coli, Klebsiella spp., no important growth/contamination (cases with CM signs but no bacterial growth observed in the culture sample) and cases with contamination ( $\geq 3$ pathogens in sample), other treatable organisms (includes CM due to Citrobacter, Corynebacterium bovis, Enterobacter, Enterococcus, Pasteurella, Pseudomonas, or others), and other not-treatable organisms (includes CM due to Trueperella pyogenes, Mycoplasma, Prototheca, or yeast)], and other non-CM diseases (milk fever, retained placenta, metritis, ketosis, displaced abomasum). The reference category comprised cows not experiencing that type of CM (i.e., other treatable or other not-treatable) in a given lactation.

${ }^{2}$ Time of milk measurement in relation to CM occurrence.

${ }^{3}$ The first CM case is due to, for example, "other treatable"; second and third cases could be due to any pathogen, not necessarily "other treatable."

${ }^{4}$ The second CM case is due to, for example, "other treatable"; first and third cases could be due to any pathogen, not necessarily "other treatable."

${ }^{5}$ The third CM case is due to, for example, "other treatable"; first and second cases could be due to any pathogen, not necessarily "other treatable."

${ }^{*} P<0.05$

major pathogen (Lam et al., 1997). Furthermore, minor pathogens, including CNS, generally cause less udder damage and have fewer detrimental consequences than major pathogens such as Streptococcus spp., Staph. aureus, E. coli, or Klebsiella spp. (Reyher et al., 2012).

In this study, E. coli CM was associated with large, long-lasting milk losses. Similar findings have been reported previously by Wilson et al. (1997). In our data, having a previous case of E. coli was not protective in terms of reduced severity in a subsequent $E$. coli case: cows with $E$. coli CM lost approximately the same amount of milk in each case. Given that a subsequent case necessarily occurs later in lactation, the loss relative to actual production potential certainly did not decrease.

In this study, Klebsiella spp. CM was associated with large decreases in milk yield in multiparas. These findings are in agreement with Wilson et al. (2008), who 
found that, on average, multiparous cows with Klebsiella spp. CM lost $4.9 \mathrm{~kg} / \mathrm{d}$ milk after diagnosis and for the remainder of lactation, compared with cows that did not contract CM. Cows experimentally infected with Klebsiella pneumoniae in late lactation lost $60 \%$ of their milk yield $1 \mathrm{~d}$ after challenge; by the second day, they were at only $15 \%$ of their prechallenge production and milk yield did not recover by the end of the study (4 d; Bannerman et al., 2004).

Samples from CM cases that show no growth of bacteria in classical culture systems are found worldwide. In a survey of mastitis on English and Welsh dairy farms, more than a quarter of clinical samples showed no growth (Bradley et al., 2007). Such samples may not be truly free of bacteria: in a study of 33 milk samples that were aerobic culture-negative (out of a total of 136 milk samples from mastitic cows), a different technique for identification (pyrosequencing) found DNA of mastitis-causing bacteria (including Strep. uberis, E. coli, and T. pyogenes) as well as other pathogenic and nonpathogenic bacteria (Oikonomou et al., 2012).

In spite of the frequent occurrence of CM cases with no bacterial growth, few studies have been published on their effects on milk yield. In a comparison of 2 $\mathrm{CM}$ treatment programs, cows with $\mathrm{CM}$ exhibiting no growth had slightly higher milk yield $(31.8 \mathrm{~kg} / \mathrm{d}$ on average) than did cows with gram-negative $(30.6 \mathrm{~kg} / \mathrm{d})$ or gram-positive $(28.8 \mathrm{~kg} / \mathrm{d}) \mathrm{CM}$ (Lago et al., 2011).

The "other treatable" category in our study included Citrobacter, Corynebacterium bovis, Enterobacter, Enterococcus, Pasteurella, and Pseudomonas. Milk losses were quite modest for this group, which might be expected; Schukken et al. (2012) reported less clinical severity in Enterobacter spp. IMI than in E. coli or Klebsiella spp. IMI. Pseudomonas spp. was also not reported to be associated with severe milk loss (Wilson et al., 1997). Pasteurella spp., however, has been associated with large declines in production (Wilson et al., 1997).

The "other not treatable" category in our study included T. pyogenes, Mycoplasma, Prototheca, and yeasts. Substantial milk losses were associated with these pathogens in both parity groups regardless of case number. Previous studies have also reported lower production in the presence of $T$. pyogenes (Wilson et al., 1997; Ericsson Unnerstad et al., 2009). Ericsson Unnerstad et al. (2009) speculate that the low milk yield associated with $T$. pyogenes mastitis arises from this infection being destructive to the milk-producing epithelium. Waage et al. (2000) found that, among heifers treated for T. pyogenes CM in the periparturient period, more than half of the quarters were nonfunctional. Large milk losses have also been reported for Mycoplasma (Wilson et al., 1997; Radaelli et al., 2011),
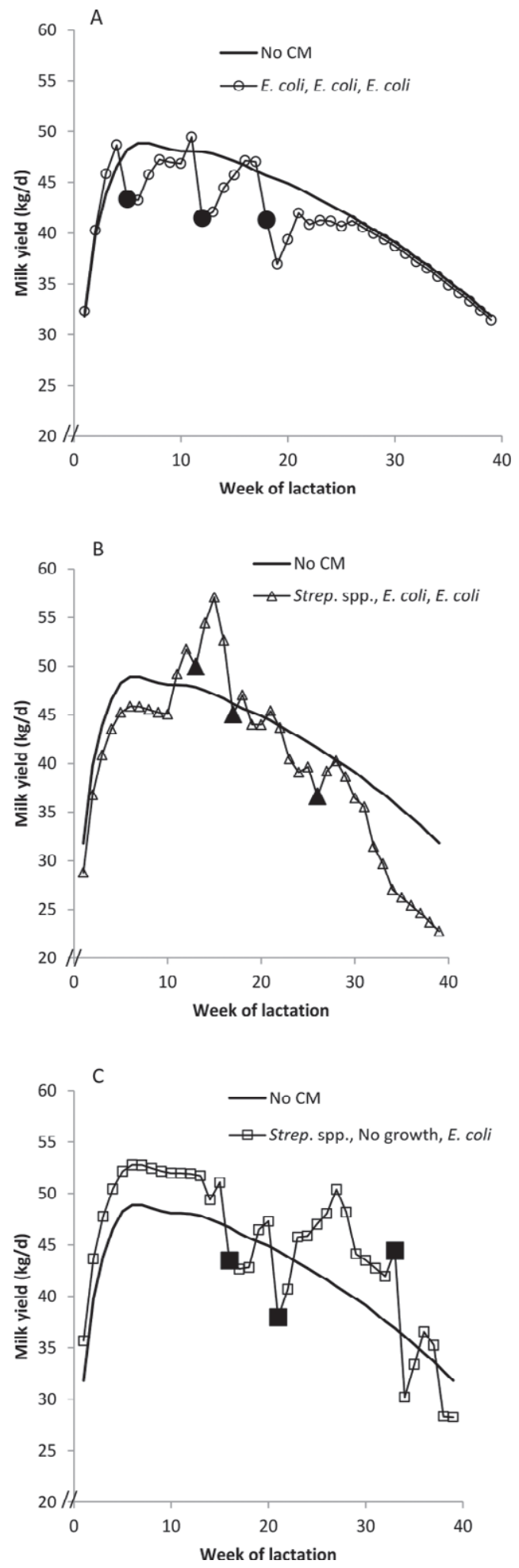

Figure 3. Predicted lactation curves of 4 parity- 2 cows: one without clinical mastitis (CM) (-); one with 3 cases of Escherichia coli $\mathrm{CM}$ occurring at wk 5, 12, and 18 (panel A; - - -); one with Streptococcus spp. CM occurring at wk 13 , and E. coli CM occurring at wk 17 and 26 (panel B; $-\Delta-$ ); and one with Streptococcus spp. CM occurring at wk $16, \mathrm{CM}$ with no important growth occurring at wk 21 , and $E$. coli $\mathrm{CM}$ occurring at wk 33 (panel $\mathrm{C}$; $-\square-$ ). Large, solid symbols indicate the week of occurrence of each CM case. 
Prototheca (Wilson et al., 1997; Bueno et al., 2006), and yeast (Wilson et al., 1997; Gaudie et al., 2009).

In this study, we also examined whether a difference existed in the effect on milk production between the same versus different pathogens in subsequent $\mathrm{CM}$ cases. The reference group was lactations that did not have CM. In primiparas, if the pathogens were the same in cases 1 and 2, a small, but statistically significant, milk loss occurred. If the pathogens were different, the loss was slightly smaller. In multiparas, a small but statistically significant milk loss also occurred whether the pathogens were the same or different in cases 1 and 2. In both parity groups, a slight gain in milk production occurred for cases 2 and 3 whether the pathogens were the same or different. Thus, given these small differences between cases, it appears that exposure to a particular pathogen in one case does not confer protection, in terms of milk loss, against that pathogen in a subsequent case. This may not be true, however, for all species or groups of pathogens. That is, this observation may be correct for many of the most frequently occurring species (as were included in this study), but not necessarily for others.

Once a cow had had a CM case, she was at greater risk of having a subsequent case (Figure 1). Similarly, if a cow had had a case of $E$. coli $\mathrm{CM}$, she was at greater risk of contracting another E. coli CM case in the same lactation (Figure 2). Similar findings were reported by Schukken et al. (2010). Clearly, these data indicated no evidence of a protective effect of previous exposure to a particular pathogen with regard to occurrence or severity of the next CM case. The data suggest the opposite: a cow affected by CM with a given pathogen is at increased risk of a repeated case with the same pathogen or another pathogen. The reason for the lack of protection and the apparent increased risk of repeated cases is not immediately clear. Both experimental and field studies have indicated that vaccination with a bacterin of gram-negative bacteria provides some level of protection against severity of milk loss and the risk of replacement and death in gram-negative mastitis (Wilson et al., 2007, 2008). Our data, however, make it apparent that a natural occurrence of $\mathrm{CM}$ with a pathogen does not provide similar protection. Clearly, our data indicate that in naturally affected cows, the development of protective immunity does not occur. The reasons for this lack of effective immune memory are not known, but we could hypothesize that the immune response in the mammary gland is sufficiently different from the systemic response to allow this distinction. Also, the mammary gland of cows with a clinical case of mastitis may be affected or altered such that the risk of a subsequent case increases. Alternatively, cows affected with CM may have a less effective innate immune response
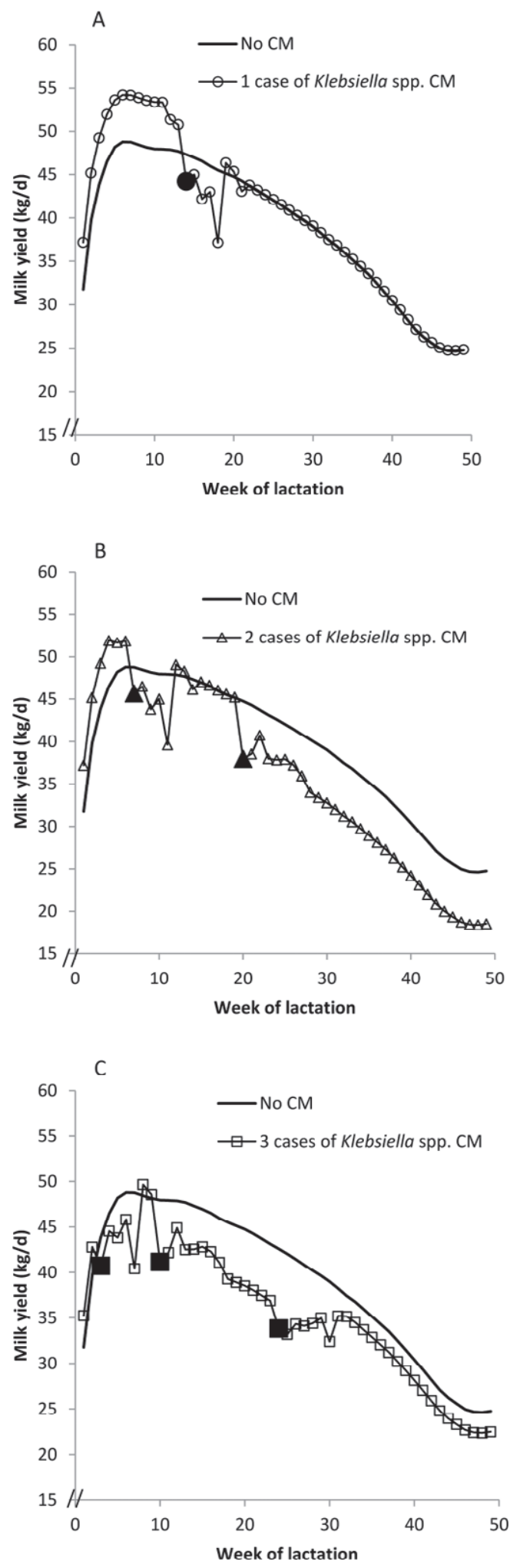

Figure 4. Predicted lactation curves of 4 parity-2 cows: one without clinical mastitis (CM) (-); one with 1 case of Klebsiella spp. CM occurring at wk 14 (panel A; - - -); one with 2 cases of Klebsiella spp. CM occurring at wk 7 and 20 (panel $\mathrm{B} ;-\Delta^{-}$); and one with 3 cases of Klebsiella spp. CM occurring at wk 3, 10, and 24 (panel C; $-\square-$ ). Large, solid symbols indicate the week of occurrence of each CM case. 
to an IMI such that the occurrence of a subsequent case is the reflection of an increased risk of CM in cows that are now identified as high-risk cows, the so-called doomed stratum (Halloran et al., 2010). These highrisk cows are not identifiable in a general population of cows that have not yet experienced a first case. If such innate increased susceptibility is indeed present, then vaccination or a natural case of CM may truly provide some protection, in cows with and without an innate increased risk of disease (Halloran et al., 2010). The concept of increased risk of repeat cases after a first case of mastitis is an important finding in this and other studies. Further research into the biological principles underlying this increased risk and the effect of it and solutions for it is clearly important.

\section{CONCLUSIONS}

In this study, decreases in milk production were observed with CM caused by different organisms. Patterns of milk loss varied with both case number and organism. The findings from this study will help dairy farmers to better assess the effect of CM cases on milk production (i.e., which pathogens are most detrimental to milk production) and the effect of subsequent cases on milk loss. The findings may also be useful in optimizing decision models that support farmers in decision making regarding $\mathrm{CM}$ cases. For example, a farmer should be more concerned about the prognosis of a cow diagnosed with $E$. coli CM than that of a cow diagnosed with CNS CM, all else about the cows being equal. The precise quantitative impact of pathogenspecific effects of CM may be obtained from the data reported here. Furthermore, the parameter estimates from the models may be incorporated into an economic optimization model that may be used for herds with similar characteristics as those in this study. Finally, our results may generate hypotheses on the presence, or absence, of immunological mechanisms that relate to the incidence rate and severity of subsequent cases of CM within the same cow within the same lactation.

\section{ACKNOWLEDGMENTS}

The USDA (CSREES) Award No. 2010-65119-20478 provided funding for this study. The authors thank owners and personnel from the 5 dairies, and the personnel of the Ithaca, Canton, and Geneseo Regional Laboratories, Quality Milk Production Services, for their valuable cooperation.

\section{REFERENCES}

Bannerman, D. D., M. J. Paape, W. R. Hare, and J. C. Hope. 2004. Characterization of the bovine innate immune response to intra- mammary infection with Klebsiella pneumoniae. J. Dairy Sci. $87: 2420-2432$

Bar, D., Y. T. Gröhn, G. Bennett, R. N. González, J. A. Hertl, H. F. Schulte, L. Tauer, F. L. Welcome, and Y. H. Schukken. 2008. Effects of repeated episodes of generic clinical mastitis on mortality and culling in dairy cows. J. Dairy Sci. 91:2196-2204.

Bar, D., Y. T. Gröhn, R. N. González, J. A. Hertl, H. F. Schulte, G. Bennett, L. Tauer, and Y. H. Schukken. 2007. Effect of repeated episodes of generic clinical mastitis on milk yield in dairy cows. J. Dairy Sci. 90:4643-4653.

Barkema, H. W., Y. H. Schukken, T. J. Lam, M. L. Beiboer, H. Wilmink, G. Benedictus, and A. Brand. 1998. Incidence of clinical mastitis in dairy herds grouped in three categories by bulk milk somatic cell counts. J. Dairy Sci. 81:411-419.

Bartlett, P. C., and J. van Wijk. 1991. Temporal patterns of lost milk production following clinical mastitis in a large Michigan Holstein herd. J. Dairy Sci. 74:1561-1572.

Bradley, A. J., K. A. Leach, J. E. Breen, L. E. Green, and M. J. Green. 2007. Survey of the incidence and aetiology of mastitis on dairy farms in England and Wales. Vet. Rec. 160:253-257.

Bueno, V. F., A. J. de Mesquita, R. B. Neves, M. A. de Souza, A. R. Ribeiro, E. S. Nicolau, and A. N. de Oliveira. 2006. Epidemiological and clinical aspects of the first outbreak of bovine mastitis caused by Prototheca zopfii in Goiás State, Brazil. Mycopathologia 161:141-145.

Compton, C. W. R., C. Heuer, K. Parker, and S. McDougall. 2007. Epidemiology of mastitis in pasture-grazed peripartum dairy heifers and its effects on productivity. J. Dairy Sci. 90:4157-4170.

Ericsson Unnerstad, H., A. Lindberg, K. Persson Waller, T. Ekman, K. Artursson, M. Nilsson-Öst, and B. Bengtsson. 2009. Microbial aetiology of acute clinical mastitis and agent-specific risk factors. Vet. Microbiol. 137:90-97.

Gaudie, C. M., P. N. Wragg, and A. M. Barber. 2009. Outbreak of disease due to Candida krusei in a small dairy herd in the UK. Vet. Rec. 165:535-537.

Gröhn, Y. T., D. J. Wilson, R. N. González, J. A. Hertl, H. Schulte, G. Bennett, and Y. H. Schukken. 2004. Effect of pathogen-specific clinical mastitis on milk yield in dairy cows. J. Dairy Sci. 87:3358-3374.

Hagnestam, C., U. Emanuelson, and B. Berglund. 2007. Yield losses associated with clinical mastitis occurring in different weeks of lactation. J. Dairy Sci. 90:2260-2270.

Halloran, M. E., I. M. Longini, and C. J. Struchiner. 2010. Design and analysis of vaccine studies. Springer Science, New York, NY.

Hertl, J. A., Y. T. Gröhn, J. D. G. Leach, D. Bar, G. J. Bennett, R. N. González, B. J. Rauch, F. L. Welcome, L. W. Tauer, and Y. H. Schukken. 2010. Effects of clinical mastitis caused by grampositive and gram-negative bacteria and other organisms on the probability of conception in New York State Holstein dairy cows. J. Dairy Sci. 93:1551-1560.

Hertl, J. A., Y. H. Schukken, D. Bar, G. J. Bennett, R. N. González, B. J. Rauch, F. L. Welcome, L. W. Tauer, and Y. T. Gröhn. 2011. The effect of recurrent episodes of clinical mastitis caused by gram-positive and gram-negative bacteria and other organisms on mortality and culling in Holstein dairy cows. J. Dairy Sci. 94:4863-4877.

Houben, E. H. P., A. A. Dijkhuizen, J. A. M. van Arendonk, and R. B. M. Huirne. 1993. Short- and long-term production losses and repeatability of clinical mastitis in dairy cattle. J. Dairy Sci. $76: 2561-2578$.

King, J. O. L. 1969. The effects of different bacterial infections causing mastitis on the yield and quality of cow's milk. Br. Vet. J. 125:57-62.

Lago, A., S. M. Godden, R. Bey, P. L. Ruegg, and K. Leslie. 2011. The selective treatment of clinical mastitis based on on-farm culture results: II. Effects on lactation performance, including clinical mastitis recurrence, somatic cell count, milk production, and cow survival. J. Dairy Sci. 94:4457-4467.

Lam, T. J. G. M., Y. H. Schukken, J. H. van Vliet, F. J. Grommers, M. J. M. Tielen, and A. Brand. 1997. Effect of natural infection with minor pathogens on susceptibility to natural infection with 
major pathogens in the bovine mammary gland. Am. J. Vet. Res. $58: 17-22$.

Natzke, R. P., R. W. Everett, R. S. Guthrie, J. F. Keown, A. M. Meek, W. G. Merrill, S. J. Roberts, and G. H. Schmidt. 1972. Mastitis control program: Effect on milk production. J. Dairy Sci. $55: 1256-1260$

Oikonomou, G., V. S. Machado, C. Santisteban, Y. H. Schukken, and R. C. Bicalho. 2012. Microbial diversity of bovine mastitic milk as described by pyrosequencing of metagenomic $16 \mathrm{~S}$ rDNA. PLoS ONE 7:e47671.

Piepers, S., G. Opsomer, H. W. Barkema, A. de Kruif, and S. De Vliegher. 2010. Heifers infected with coagulase-negative staphylococci in early lactation have fewer cases of clinical mastitis and higher milk production in their first lactation than noninfected heifers. J. Dairy Sci. 93:2014-2024.

Piepers, S., Y. H. Schukken, P. Passchyn, and S. De Vliegher. 2013. The effect of intramammary infection with coagulase-negative staphylococci in early lactating heifers on milk yield throughout first lactation revisited. J. Dairy Sci. 96:5095-5105.

Radaelli, E., V. Castiglioni, M. Losa, V. Benedetti, R. Piccinini, R. A J. Nicholas, E. Scanziani, and M. Luini. 2011. Outbreak of bovine clinical mastitis caused by Mycoplasma bovis in a North Italian herd. Res. Vet. Sci. 91:251-253.

Reksen, O., L. Sølverød, and O. Østerås. 2007. Relationships between milk culture results and milk yield in Norwegian dairy cattle. J. Dairy Sci. 90:4670-4678.

Reyher, K. K., I. R. Dohoo, D. T. Scholl, and G. P. Keefe. 2012. Evaluation of minor pathogen intramammary infection, susceptibility parameters, and somatic cell counts on the development of new intramammary infections with major mastitis pathogens. J. Dairy Sci. 95:3766-3780

Santos, J. E. P., R. L. A. Cerri, M. A. Ballou, G. E. Higginbotham, and J. H. Kirk. 2004. Effect of timing of first clinical mastitis occurrence on lactational and reproductive performance of Holstein dairy cows. Anim. Reprod. Sci. 80:31-45.

Schukken, Y., M. Chuff, P. Moroni, A. Gurjar, C. Santisteban, F. Welcome, and R. Zadoks. 2012. The "other" gram-negative bacteria in mastitis: Klebsiella, Serratia, and more. Vet. Clin. North Am. Food Anim. Pract. 28:239-256.
Schukken, Y. H., D. Bar, J. A. Hertl, and Y. T. Gröhn. 2010. Correlated time to event data: Modeling repeated clinical mastitis data from dairy cattle in New York State. Prev. Vet. Med. 97:150-156.

Schukken, Y. H., R. N. González, L. L. Tikofsky, H. F. Schulte, C. G. Santisteban, F. L. Welcome, G. J. Bennett, M. J. Zurakowski, and R. N. Zadoks. 2009a. CNS mastitis: Nothing to worry about? Vet. Microbiol. 134:9-14.

Schukken, Y. H., J. Günther, J. Fitzpatrick, M. C. Fontaine, L. Goetze, O. Holst, J. Leigh, W. Petzl, H.-J. Schuberth, A. Sipka, D. G. E. Smith, R. Quesnell, J. Watts, R. Yancey, H. Zerbe, A. Gurjar, R. N. Zadoks, and H.-M. Seyfert., and members of the Pfizer mastitis research consortium. 2011. Host-response patterns of intramammary infections in dairy cows. Vet. Immunol. Immunopathol. 144:270-289.

Schukken, Y. H., J. Hertl, D. Bar, G. J. Bennett, R. N. González, B. J. Rauch, C. Santisteban, H. F. Schulte, L. W. Tauer, F. L. Welcome, and Y. T. Gröhn. 2009b. Effects of repeated gram-positive and gram-negative clinical mastitis episodes on milk yield loss in Holstein dairy cows. J. Dairy Sci. 92:3091-3105.

Waage, S., H. R. Skei, J. Rise, T. Rogdo, S. Sviland, and S. A. Ødegaard. 2000. Outcome of clinical mastitis in dairy heifers assessed by reexamination of cases one month after treatment. J. Dairy Sci. 83:70-76.

Wilson, D. J., R. N. González, and H. H. Das. 1997. Bovine mastitis pathogens in New York and Pennsylvania: Prevalence and effects on somatic cell count and milk production. J. Dairy Sci. 80:2592-2598

Wilson, D. J., Y. T. Gröhn, G. J. Bennett, R. N. González, Y. H Schukken, and J. Spatz. 2008. Milk production change following clinical mastitis and reproductive performance compared among J5 vaccinated and control dairy cattle. J. Dairy Sci. 91:3869-3879.

Wilson, D. J., B. A. Mallard, J. L. Burton, Y. H. Schukken, and Y. T. Gröhn. 2007. Milk and serum J5-specific antibody responses, milk production change, and clinical effects following intramammary Escherichia coli challenge for J5 vaccinate and control cows. Clin. Vaccine Immunol. 14:693-699.

Zhao, X., and P. Lacasse. 2008. Mammary tissue damage during bovine mastitis: Causes and control. J. Anim. Sci. 86:57-65. 